\title{
Methodological Challenges of Traditional and Virtual Anthropological Fieldwork in Migrant Integration Research: the Case of Chinese-Hungarian Interethnic Partner Relationships
}

\author{
Nóra Kovács \\ Hungarian Academy of Sciences Centre for Social Sciences, Institute for Minority Studies \\ kovacs.nora@tk.mta.hu
}

\begin{abstract}
The paper is based on a piece of anthropological research on ChineseHungarian mixed partner relationships. This qualitative research on the intimate relations between members of a highly transnational migrant population and members of local Hungarian society posed a number of methodological challenges. A substantial segment of the data was collected through ethnographic fieldwork where the otherwise non existent ethnographic field (i.e. no community formed by mixed couples; the lack of a geographical or an online locality) was defined by the initially formulated research questions. Fieldwork was complemented by the collection of diverse data from computer mediated communication carried out by members of Chinese-Hungarian couples and their family members, however, combining information available in online space with data gathered through face-to-face interaction has proved to be problematic.
\end{abstract}

Keywords: migration, Chinese-Hungarian intermarriage, research methodology, fieldwork in fragmented field, computer mediated qualitative data

(C) Centre for Population Studies 


\section{Introduction}

This paper is based on a piece of anthropological research on ChineseHungarian mixed partner relationships. ${ }^{3}$ Focusing on the role of the different social and cultural backgrounds in the lives of couples, the research project addressed a series of questions concerning mixed partner relationships as a global migration related social phenomenon, as an aspect of first generation Chinese migrants' presence in Hungary, and also as a channel of Chinese migrants' integration. ${ }^{4}$ This experience based paper reflects on everyday challenges and practical matters that emerged during anthropological fieldwork.

There are different ways the normative concept of integration is treated in social sciences discussing migration related phenomena. It often refers to the structural integration of migrants through the labour market, citizenship, participation in the education system, language acquisition, intermarriage, to mention some examples. In the following discussion integration is thought of and interpreted as a series of events that happen through personal interaction in intimate relations. More specifically, it refers to personal interactions as narrated by Chinese and Hungarian individuals. Although I had equal interest in the everyday practices of the lives of mixed couples, I gained systematic access mostly to what they said about their shared lives and not what they actually did. This paper is concerned with the methodological challenges of research on the specific reality of ChineseHungarian interethnic partnerships from a Hungarian point of view.

It is unknown exactly how many Hungarians are married to or cohabit with Hungarians and even less how many Chinese and Hungarian persons date each other. There is no relevant statistical information available on ChineseHungarian marriages or cohabitations. Data on the marriages between Chinese and Hungarian citizens are not gathered by a central office; these figures are recorded separately in district registry books. Based on informal communication with registrars of Budapest districts number 6,7 and 10 there were about one or two such marriages per year in the period between 2009 and 2013, including inconveniently also marriages between Chinese citizens and ethnic Chinese migrants turned Hungarian citizens. Several relationships encountered during fieldwork were not registered marriages, whereas the majority of those who formalised their relationship got married outside

\footnotetext{
${ }^{3}$ The work on mixed couples formed part of a thematically wider research project on the intimate relations between Chinese migrants and Hungarians. Besides mixed partner relations, childcare arrangements between Chinese families and Hungarian carers were concentrated on.

${ }^{4}$ Some results were already published. See Kovács $(2015,2016)$.
} 
Hungary, in China or in a third country. Official marriage records may also include Chinese-Hungarian sham marriages which, interesting a phenomenon as they may be, were not included in this project. ${ }^{5}$ What fieldwork data showed was that the earliest Chinese-Hungarian relationships could be dated back to the early 1990s, so, with a single exception, not even the longest-lived relationships could have lasted for more than two and a half decades.

Although initially I wanted to interview married couples and their families, later dating, cohabiting, divorced and separated persons were also approached, since their experiences contributed largely to the understanding of the everyday dynamics of interethnic partner relationships. This widening of the original focus is reflected in the interchangeable use of the terms marriage and partner relationship throughout the text.

\section{Highlights of the Chinese migrant context in Hungary}

Although Hungary cannot be considered a typical immigration country, it has been affected by several waves of inward migration for the last three decades. Most migrants were ethnic Hungarians arriving from neighbouring countries, but the largest visible group was that of the Chinese migrants exceeding forty thousand by the mid-1990s. Challenging a task as it was, they were targeted by several research projects, and demographic, social, economic, educational, gender and identity aspects of Chinese migrants' presence in Hungary were already studied (Nyíri 2006, 2010a, 2010b; Várhalmi 2009; Beck 2015; Kovács 2015, 2016; Kovács \& Melegh 2010; Szabó 2009; Feischmidt \& Nyíri 2006). Chinese migrants arrived in massive numbers from the early 1990s, and by the mid-2010s their number fell to fifteen thousand. ${ }^{6}$ During this period their principle business model has changed from shoes and clothes retail to local and regional wholesale of a wider range of Chinese products, several Chinese businesses growing large and becoming very successful economically along the way. As their demographic characteristics, as potential actors of the Hungarian marriage market of the 1990 s are concerned, there were almost as many women as men among them mostly in their twenties and thirties, some arriving alone; a relatively high proportion with some form of tertiary education. Literature hinted at the lack of the norm of endogamy among Chinese migrants in Hungary (Nyíri 2010b:153)

\footnotetext{
${ }^{5}$ I did not meet members of Chinese-Hungarian sham marriages, that is, marriages of convenience entered into solely for the benefits of married status. Throughout the fieldwork, several Chinese as well as Hungarian persons commented on their existence. See also the section on culturally embedded concepts.

${ }^{6}$ Based on informed estimates of representatives of the Chinese community in Hungary.
} 
The group of Chinese migrant entrepreneurs in Hungary have operated their businesses on a transnational basis, and lead a transnational way of life with persons and resources in constant flow between Hungary and China, and sometimes also other locations in the European region or the Americas. The way Chinese migrants and migrant entrepreneurs and Chinese businesses operate in Hungary was most recently discussed by Várhalmi $(2009,2013)$.

Many first-generation Chinese migrants were disinclined to take out energy from their businesses to invest in learning Hungarian leaving the task of translation for the family business to the school age second generation. They established a way of life and arranged their businesses in a way that learning the local language was not essential for them. Signals from local society may have contributed to this. Studies have indicated that Hungarians manifested negative attitudes towards Chinese migrants (Örkény \& Székelyi 2010; Szilassy 2006).

My fieldwork has supported this with many personal ethnographic details, with events ranging from discrimination at kindergarten and school, or in sports associations, through verbal offence and verbal aggression to occasional physical insult. Verbal attacks in public spaces were often reported to have targeted mixed marriage children and youth, or Hungarian women accompanying Chinese-looking children or Chinese men. A Hungarian father related the episode of travelling with his four-year-old Chinese-Hungarian son using the public transport in Budapest. Trying to work their way off the packed tram at the rush hour he stepped down first reaching out a hand to help his son get off. It was in this moment when a young man waiting to get on the tram yelled at the boy in a hoarse voice 'Hurry up your ass, yellow motherfucker!', leaving the Hungarian father dumb and helpless. Most such Hungarian offenders in my field experience were reported to have been teenage boys or young men.

Several mixed marriage parents commented on similar experiences of their children and some of them chose the Chinese-Hungarian bilingual school as an escape route from negative experiences and isolation at school. Lacking space to go into details of relevant ethnographic experience about this here, let me also note that there are a set of cultural spaces in Budapest such as Chinese tea houses, traditional Chinese sports associations, Mandarin and calligraphy courses, centres for traditional Chinese medicine, top quality Chinese restaurants where interactions between Chinese migrants and a select group of Hungarians are defined by the appreciation of and an exotic longing for the rich Chinese cultural traditions these institutions represent. 


\section{Research questions, research aims}

As it was mentioned above the majority of Chinese migrants who arrived in the 1990s became transnational economy based entrepreneurs. They are called 'typical migrants' throughout the text. The plan of the research was originally driven by the assumption (Nyíri 2006: 44) that few interethnic partner relationships were formed by 'typical Chinese migrants', and Hungarians, compared to the relative size of this migrant population. One of the research questions was what could explain the supposedly low incidence.

It was another research aim to study and understand the everyday reality of living in a Chinese-Hungarian mixed partner relationship in Hungary and to reveal how the cultural differences between partners' socialization contributed to the inner dynamics of these bonds. Are Chinese-Hungarian partner relationships more or less likely to be persistent in time than similar bonds between Hungarians? Are these bonds more or less likely to be satisfactory for the individuals who constitute them than ethnically homogamous relationships?

Are there cultural factors that have a substantial influence on the stability of Chinese-Hungarian mixed partnerships? Does stability in this respect have a culturally conditioned gender component to it? In what way do members of couples perceive and reflect on the fact that their partner's emotions and their forms of expression are culturally conditioned?

Another aim of this research was to find out whether these bonds shared certain features allowing for categorisation and a Chinese-Hungarian relationship typology. Transnationalism, a fundamental aspect of the lives of Chinese entrepreneurs based in Hungary was an important focus of research. Do all members of Chinese-Hungarian mixed couples and families become transnational the same way as their Chinese member is likely to live a transnational way of life? Are transnational practices in these families' lives connected to business models and economic success? How are transnational practices related to individual and family language strategies? What are the consequences of the individual and family language strategies in the couple's or family's life? What was the connection between language strategies and family members' transnationalism? Can childcare and education strategies and solutions be seen as fundamentally related to and part of Chinese migrants' transnationalism? How are problems related to transnationalism negotiated in a mixed marriage or family? Some results of the research were published (Kovács 2015, 2016) and I would like to emphasize that important results lie in ethnographic details. Space is limited here; nevertheless, some general findings are referred to briefly in a simplified way. In spite of their great individual 
differences, the sample of forty couples outlined two characteristically different types of relationships. The first type is referred to as 'student love' relationships, and it is characterized, most of all by closeness in educational status. The 'student love' sub-group of very highly qualified couples with a high value on the international labour market seemed even more successful relationships. The second type is the relationship of the 'typical Chinese migrant' with a larger social and often educational distance between its members. Relationships in the former group tend to be more successful and persistent in time, whereas the latter are considerably less persistent. ChineseHungarian relationships studied in this research were more persistent in time if the Chinese partner was female. Research confirmed literature stating that in spite of changing Chinese family relations, Chinese family culture is very characteristic and relatively persistent (Efron Pimentel 2000). Hungarian partners' fluency in Chinese and their understanding of, putting it in an oversimplified term, Chinese ways improved prospects of a mutually satisfactory relationship. 'Typical migrant' men's spouses or children contacted during research showed no, or only a very low degree of transnationalism.

I would also like to note that a Chinese and a Hungarian interlocutor of the highly qualified and internationally mobile sub-group of 'student love' relationships pointed out that marriage and family related norms and social practices were changing rapidly in China and the observations made in Hungary would not necessarily hold in all segments of Chinese society.

\section{Methodological challenges}

The anthropological approach to the intimate relations between members of a highly transnational migrant population and members of local Hungarian society raised several methodological problems. Some of them were variants of classical problems anthropologists encounter during fieldwork intertwined with others that, compared to previous research experience with geographically concentrated or community based anthropological fieldwork, required special methodological attention. Bearing in mind this research framework, in the next part of the paper the following points are going to be addressed: 1) the topic specific definition of the ethnographic field and fieldwork; 2) the use of written and visual sources from the digital world; 3) the epistemological value of long term fieldwork as a research method; 4) ways of handling the lack of information; 5) strategies to use and interpret narratives of third parties; 6) ways of handling culturally conditioned strategies of communication, especially that of intimacy; 7) ways of handling socioculturally embedded concepts; 8) considerations about masking interlocutors' identities; 9) personal 
position of the researcher as a factor conditioning the type of information accessed; and 10) the public afterlife of the ethnography. Wherever possible, the problems are going to be presented with examples from the field.

\section{The ethnographic field of Chinese Hungarian mixed partner relationships}

Data was collected through ethnographic fieldwork including interviews. At first it was not quite clear for me where my ethnographic field lied so I searched for it everywhere, including within my personal network and that of friends. What the ethnographic field is, where it lies, and its borderlines were initially unclear since mixed couples formed no communities or institutions and they could not be tied to one particular geographical locality or localities. I was inspired by George E. Marcus's handling of this problematic letting the object of study describe its field (Marcus 1995). Nevertheless, the field had to be constructed and reconstructed in an effortful way several times. The concept of multi-sited ethnography seemed appealing at first, however, during the course of fieldwork I eventually preferred to describe it as fragmented (see Nagy 2015: 46). The research-specific rules of what fell within or outside the scope of the ethnographic field had to be modified from time to time as new bits and pieces of information opened new paths to trace.

Looking back at the fieldwork process and tracking down its subsequent phases, the first set of field experiences were collected through intensive Chinese language courses taken at one of the two main authentic Budapest language academies specialized in Mandarin Chinese, and later through individual classes taken from a Hungarian teacher of Chinese, throughout a period of altogether three years. My Hungarian Chinese professor had several years of experience living and studying in Beijing and besides cultural and historical issues of China he was also knowledgeable about representatives of different aspects of Chinese culture in Hungary, such as Chinese martial arts associations, Chinese medical experts, and official representatives of the PRC in Hungary. While he was familiar with and an enthusiast of China's cultural, economic and scientific achievements, he also seemed highly critical of some of their 'purely business oriented' representatives in Hungary, Chinese and Hungarian alike. His confronting attitude has made him an isolated figure in a cultural field that one might label as a 'Chinese-Hungarian cultural encounter zone in Budapest'. With years of experience as a foreign student at Chinese universities he gave me insights into the beginnings and workings of one type of Chinese-Hungarian partner relationships that later was labelled as 'student love'. The distance he kept from 
the actors of this encounter zone also kept him outside the dense network of trust and possible reciprocal favours - to be explained further. It was only much later that I realized how important it was to (in one way or another, temporarily) be included in such a network, existent mostly between Chinese migrants but also some Hungarian individuals, to obtain information for the research I wanted to carry out. Determined to study Chinese-Hungarian mixed marriages but having no contact with any of them I asked relatives, friends, colleagues, and neighbours for help. It came unexpectedly from a member of my family with a double career in business and academia.

He connected me with a second-generation Chinese man, a former student in his late twenties, referred to here as Young Yu. Young Yu was a close friend of one of my relatives business partners since their shared time at university, now associate in a well-known and leading financial firm. They encouraged me to connect Young Yu who had given his consent. We arranged a date where Young $\mathrm{Yu}$ appeared accompanied by his father, wealthy and educated Mr. Yu, owner of a very successful transnational family enterprise. As a matter of fact Young Yu came along as his father's translator since Mr. Yu spoke no Hungarian. We met in a café in a shopping mall close to the Chinese commercial district. Mr. Yu arrived prepared with a list of mixed marriages he and his wife knew of. All his statements were supported by newspaper cuts from local Chinese papers. He went through the case one by one and shared some details with me. He gave me the impression that he did not want to say more than what was included in the papers he brought me, giving at last his general statement: there were few Chinese-Hungarian marriages, and usually they did not work out well. We talked for two hours with the assistance of Young $\mathrm{Yu}$ who did not seem involved in our conversation and kept to translating his father's sentences attentively. After our meeting, the father and son proposed to show me the location of their business and offered me a ride there and back to the shopping centre. I travelled in Young Yu's fabulous car and $\mathrm{Mr}$. Yu took his own to show me their extensive property in the $10^{\text {th }}$ district of Budapest. They seemed proud to let me know that over two thirds of the land and buildings I was seeing was purchased by Chinese entrepreneurs including their family headed by Mr. Yu. After a short walk among the shops and warehouses Young Yu drove me back to the shopping centre.

Their helpfulness was in sharp contrast with subsequent experiences of rejection by potential interlocutors during fieldwork. Trying to make sense of why Mr. Yu and his son helped me drew the attention to a fundamental component of my fieldwork. Through the bond between the two trusted, respectful and successful mutual acquaintances I temporarily became part of a 
network of trust, respect and potential favours while the Yu family did not have to give away sensitive personal information. There was only a light violation of the norm of keeping important information from third parties on his part: the information he gave was available publicly and he only provided me with some extra clues.

The lack of this relatedness through trust or possible favours, or a sudden change of the researcher's indirect position within the network could impede access to information that seemed to be within arm's reach. A Hungarian friend's teenage son was dating the daughter of a successful Chinese businessman married to a Hungarian woman. The mixed family lived in an elegant villa on the Buda side and was reported to have achieved very good economic standing through the father's transnational trading activities. I was eager to meet this couple since they seemed to represent the rare group of functioning marriages between a 'typical migrant' man and a Hungarian woman, with children and decades of shared experience. I talked to the wife on the phone to arrange a date for the interview she had consented to. The week before the date set I called her to specify location and she told me that she could not do the interview after all. It was a couple of days later I learned that my friend's son broke up with her daughter, an incident that removed me from a trusted circle of possible favours. In summary, interviews were only made possible through some form participation in networks of friendship or business with a hope of gaining some kind of symbolic return on possible interlocutors' part. A Chinese person's reasons to cooperate in the research cannot be interpreted without references to degrees of integration in social networks.

And finally, I would make a remark about my personal perception of the repeated fieldwork experience of how Chinese migrants handled time. Whenever I had the opportunity to call a Chinese person about an interview I was either turned down immediately, or if not, I heard that person consider time options to meet, often making an excuse for not being able to meet that very same day and offering the day after instead. It seemed that something that had to be done, had to be done as soon as possible, giving a hint on how a Chinese business person can quickly and successfully adapt to a changing economic environment. The same attitude was reflected in remarks on Chinese entrepreneurs' ability to adapt quickly to changes in the economic environment (Várhalmi 2009). 


\section{Digital sources from the online world}

The online world as an object or location of ethnographic fieldwork was systematically introduced into social sciences by Christine Hine's Virtual Ethnography (2000) connecting computer mediated communication (see Hine 2000) with the possibility of doing ethnography research in and of the internet.

The question of what fell within my ethnographic field became more intense once I entered virtual space and searched for computer mediated communication carried out by or available about members of ChineseHungarian couples and their family members. The wide variety of online sources included visual information such as publicly accessible video recordings, photos, personal avatars as self-representations on community media sites; personal profiles and networks on community media sites; online documents such as entries in the online business register that were informative of whether, for example, Hungarian spouses are at least formally included in their Chinese partners' businesses as local associates or not; online chat streams on mixed coupledom; Hungarian and Chinese newspaper articles on mixed couples' and their children's public activities.

Members of mixed couples are located at the intersection of two online worlds where the lack familiarity with the written language of one another kept up a boundary for many of them, both Chinese and Hungarian.

Some couples I succeeded in interviewing, others I did not. Even if ethical considerations as to how these sources can legitimately be included in research were set aside for a while, the qualitative richness raised dilemmas. I often lacked the possibility to trace further these pieces of information and provide them with as much context as it could be expected in traditional fieldwork based research.

The story of an interlocutor's relatives, a couple with a teenage daughter who never married but cohabited on and off for a few years before they separated definitively may offer an example. Theirs was a relationship of the most problematic type encountered, that of a 'typical Chinese migrant' man with no tertiary education arriving in the 1990s from a rural area of China who built up a prosperous transnational enterprise from scratch with his siblings. It became quite clear that my interlocutor was in no position to provide me with access to them. She commented that ever since the separation the Chinese father (and his Chinese kin resident in Hungary) kept very occasional contact with the young girl who felt abandoned and very different in a Hungarian small-town context and who was desperate to have her Chinese father's attention. Being familiar with the girl's name and town of residence I 
made a Google search and found her unprotected profile on a teenage community site. Her avatar was an East-Asian female manga character, a sad and solitary young woman set in a hostile urban environment. Intimately revealing as this may be about a Chinese-Hungarian mixed marriage child's personal identity I was confined to these pieces of information and could go no further.

At one point during fieldwork it was not clear at all how the visually presented and subtle information in a one hour long amateur video indexed and openly available online and recorded at a public event involving a Chinese man and his mixed marriage family is going to be made useful for research purposes. The recording showed all family members at a vernissage in an art gallery where they moved around demonstrating gestures and body language that suggested separation between the spouses. It also showed the presence of the Chinese man's new Chinese partner, and presented father and children keeping a physical distance at all times without interchanging words. This family had been in the focus of my attention for a long time with no possibility to make an interview before I found this recording. Fortunately, later on the Hungarian wife agreed to a conversation and told me the story of her marriage; she put the images I saw into words providing a context to them.

Likewise, two brief accounts in the Hungarian electronic edition of a local Chinese online newspaper told the stories of two failed marriages between Chinese women and Hungarian men from a Chinese point of view. Fragmentary, short of ethnographic detail, and unclear about the women's motifs of entering in the relationship, the two paragraphs presented the sad fate of these bonds between Chinese wives and their Hungarian husbands as inevitable.

A chat stream associated with the online edition of a Hungarian women's magazine on the topic of mixed marriage provided scattered and anonymous information, nevertheless, the comments on and experiences of Chinese-Hungarian dating relationships emphasized certain themes, such as the verbal aggression against Hungarian women dating Chinese men; and also showed cases of passionate defence of Chinese migrants supported by their work ethic.

Internet searches for the computer mediated communication of members of Chinese and Hungarian couples brought many results which, at the same time, showed a relatively low level of participation of these firstgeneration Chinese persons on Hungarian community media sites. No systematic study within this research project focused on this, but they seemed to be absent from Hungarian social media sites, such as Facebook. There could 
be many reasons for this, among them the fact that Facebook cannot be used in China where other Chinese sites such as WeChat or Weibo are popular; and also, that using these sites requires English or Hungarian language proficiency. Bearing in mind the often mutually limited language capacities of persons involved in these relationships I would like to draw attention to the two the partners' parallel online universes separated by languages.

\section{Long term anthropological fieldwork - was it worth the effort?}

Long term fieldwork has been considered an indispensable anthropological research method defining the discipline ever since Malinowksi's pioneering venture (Malinowski 1922) in the Trobriand Islands nearly a hundred years ago. Anthropological reflections and theorizing about various aspects of fieldwork, it's epistemological value, the anthropologist's role in the ethnography produced and her position in the studied community have been topics at the fore of the discipline for many decades now. There have been several crucial attempts to re-conceptualise anthropological fieldwork shifting its focus from simple to complex societies and from foreign worlds to that of the anthropologist's own, including more recently the practice and notion of fieldwork conducted in the world of the internet. A summary published in Hungarian by Károly Zsolt Nagy (Nagy 2015) outlines this process.

As a sociocultural anthropologist working in an interdisciplinary academic environment surrounded by social science scholars with a different and perhaps more economical vision of the time and other resources spent on data collection, I felt the need to scrutinize the epistemological worth of the extra efforts invested in fieldwork towards the understanding of the workings of the intimate relationships between Chinese migrants and their Hungarian partners. $^{7}$ This question may as well be rephrased to ask what results other methodologies, such as a survey type of research on Chinese-Hungarian interethnic partner relationships would yield.

A phenomenon of similar magnitude would most likely not invite quantitative methodology. More importantly, the people involved in these relationships, particularly from the Chinese side, were often reluctant to contribute, and especially so without a close friend's recommendation, making other potential research methodologies unviable.

Trying to assess a migration related phenomenon surrounded by predominantly negative preconceptions in Hungary may easily lead to the formulation and use of labels that Elizabeth Durham (2016) refers to as

\footnotetext{
7 Time after time anthropologist may also experience that editorial suggestions make them painfully remove ethnographic details from journal articles to meet size requirements.
} 
culturalisms or cultural keys, that is, simplified and potentially under informed explanations of socioculturally conditioned practices and norms. Using the example of authorities' inability to efficiently communicate medical information on the Ebola fever to locals Durham contrasts culturalisms and cultural keys to substantiated anthropological knowledge, concluding that everything is more complicated and complex than it seems (Durham 2016). Interlocutors' multiple voices during fieldwork helped build up a multidimensional reality of at least some Chinese Hungarian mixed couple relationships where partners' decisions, conflicts, actions, intentions were discussed in relation to their sociocultural backgrounds and life experiences.

As indicated in the section on the ethnographic field, fieldwork started a long time before the research project outlined in this paper took its final shape, with intensive language courses and later individual classes, and a systematic attempt to attend public social events where Chinese and Hungarian people met outside the world of commerce where. This was an exciting and research-wise inspiring yet time and money consuming process I nevertheless considered indispensable. It gave an overview of where one may find couples and what are the ways to approach them that definitely did not work; and it produced clues to knowledgeable individuals as potential cultural consultants.

There are some methodological advantages of extended fieldwork that stand against its high costs and lengthy process. Even if the ethnographic field is fragmented fieldwork made it possible to meet some interlocutors more than once. It allowed for the patience to wait until some encounters could happen. Importantly, in a few cases it opened up the possibility to follow subsequent stages of the relationships adding a dynamic component to the analysis. It created opportunities to fill in information gaps making phone calls or via email, or the incorporation of previously unplanned sources of information, or discovery of some of the mistakes committed previously. Also, a continuous personal involvement in the data collection process offered some degree of visibility for interlocutors.

The ethnographic fieldwork towards the world of Chinese Hungarian mixed couples had its limitations. This was caused primarily by the fragmented quality of the field leading to fresh start situations during fieldwork way too often. Separated or divorced couples and subsequently fragmented families further aggravated this. Chinese partners' transnational mobility and periodical absence from Hungary also complicated the fieldwork process. 


\section{Missing information}

As it was suggested in the introduction, there are several conditions that challenge research on migrant groups in Hungary. The Interdisciplinary Centre for Comparative Research in the Social Sciences (ICCR) in Budapest organised a series of seminars on the methodological challenges of migration research in Hungary and published its results in an edited volume (Kováts \&Várhalmi 2014). The introduction enlists five conditions/circumstances that challenge migration research in particular: 1) the low number of migrants with no segregation or migrant neighbourhoods; 2) the lack of relevant statistical information available about migrants; 3 ) the risks concerning the validity of empirical sampling; 4) the difficulties arising from culturally different norms of interpersonal interactions; and 5) the lack of trust related to the social distance between migrant groups and majority society (Kováts \& Várhalmi 2014: 9-10). One of the central problems addressed was the methodological treatment of data gaps and missing responses in survey types of enquiries.

Anthropological fieldwork extended in time helped overcome some of these difficulties to a certain extent. With time, several people involved in mixed partner relationships living in different neighbourhoods were identified, contacted, and interviewed. Having an idea of their existence, attempts could be made to find additional information about them in different forms of computer mediated communication. Conducting anthropological fieldwork, the problem of the validity of sampling was reflected on in the ethnography. Nevertheless, several obstacles stood in the way of giving balanced pictures of the individual cases. According to the original aim, both persons involved in a relationship should have been interviewed but it was generally only one of them willing to share experiences. Partners interviewed together talked more tactfully in each other's presence than individual interviewees and thus proved to be generally less informative. On the other hand, partners who were interviewed separately tended to give richer accounts than the ones interviewed as a couple.

Gender sensitive social science literature on relationships has suggested that there exist two, often very different or contradictory personal versions of the same relationship (see for example Efron Pimentel 2000: 35). In more than half of the interviewed cases it was either his or her version that the interpretation was based on and the story remained one-sided, tempting speculation. The conversations with two Hungarian women both in their thirties and involved with Chinese men in their early fifties raised the question in what way and to what extent their relationship narratives would correspond to that of their Chinese partners. 
One of the women, let's call her Kati, a highly qualified professional with experience in China and very advanced Chinese language skills, was romantically involved and had a child with a married politician of the PRC who was reported to be about to divorce his wife whom he had married obeying his parents' command. Their child was about two at the time of the interview and lived with Kati who expressed an explicit intention to find a job and realize her and her partner's shared dream of uniting their family in China. Conceived during one of his father's international trips, the child had met his father on one occasion in a third country during his dad's official visit there. Kati and her child communicated online with the Chinese father in prearranged time periods on a regular basis, but it was their explicit intention not to be online permanently. A recent communication with Kati two and a half years after the first interview revealed that she and her child were still living on their own in the Hungarian capital where she was working full time. When asked to give a second interview about how their relationship and family life developed ever since, Kati responded that she would prefer not to talk about these things, noted that their plans and mutual affection for one another did not change but both her and her partner's situations are delicate and require discretion.

The other Hungarian woman, Piri, a secretary with no tertiary education or Chinese language skills met her 'typical Chinese businessman' fifteen years her senior at an online Hungarian dating site eight years prior to our conversation. They had corresponded for a year before their first date and their subsequent encounters developed into a romantic affair slowly. Although she expressed hopes in this respect, the two of them had never moved in together nor did her Chinese boyfriend ever express his intention to do so, but she thought that she just had to be patient and it would happen. He always met her on his own and she said to have met none of his Chinese friends or relatives living in Hungary. On our first encounter during fieldwork interlocutors were encouraged to tell about themselves only as much as they felt comfortable with. This was the case in which an interviewee made most use of this instruction commenting time after time that her boyfriend probably wouldn't like her going into further details about his name, business, hobby, family status, and Chinese relatives living in Hungary, basic things she seemed to have been familiar with but what he may have considered qualified information. In both cases Chinese, male partners' narratives and viewpoints would have been crucial to the understanding of the definition and inner dynamics of these relationships. Although it was extended in time, fieldwork opened no doors for me to be able to listen to the men's versions of these 
50 Romanian Journal of Population Studies $\bullet$ Vol. XI, No. 1

relationships directly. Some possible reasons for this are going to be discussed further on.

\section{Information from third parties}

Personal friends and acquaintances who had known Chinese-Hungarian couples made an important contribution to the fieldwork process. They provided the first clues about the existence of some of these bonds. In a few cases narratives of couples' intimate friends became central sources, especially where no interview was possible. The group of potential interviewees least likely to share experiences with me and least accessible during fieldwork were Chinese men.

A Google search on mixed marriage had helped identify a couple, Petra and Ping, living in Budapest and married with children for nearly two decades. Computer mediated communication including their relationship story, family photos, business websites, and chat room comments suggested that not only did they work together but they also shared political opinions, leisure time activities, and religious faith. They, however, preferred not to be interviewed. It was thanks to a male friend's accidental encounter with Ping, the Chinese businessman, on a long hiking experience in the countryside, and his sharing it with me that gave insights of an otherwise inaccessible viewpoint during this research, that of a Budapest-based Chinese businessman living with and caring for his mixed marriage family. The two men, both in their late forties, walked together for several hours talking over sports, business and family. Discussing issues related with fatherhood Ping expressed his regrets of having not forced his children to learn Chinese when they were young. Referring to his teenage kids his said "he committed a mistake; that it went wrong, and it was all too late to change."

In a few cases third persons' knowledge of couples outlined a reality quite different from that expressed in interlocutors' narratives. In their interpretation of a few cases Chinese men's Hungarian girlfriends or cohabiting partners appeared as persons "blind to see their real position in the relationship," implying that they may not have been included in their Chinese partners long term plans, or that the men may have had a wife and family back in China.

\section{Deciphering culturally conditioned norms and strategies of communication}

The acquisition and skills of the languages used by the studied group, in this case Chinese and Hungarian, are considered a prerequisite of anthropological 
fieldwork. Mandarin studies were referred to in the section on fieldwork, however, it must be noted that I did not reach the necessary fluency in Chinese to obtain the type of qualitative information this research required. It raised the question whether or not the lack of ability to communicate fluently in half of the potential interlocutors' mother tongue was a major obstacle. My fieldwork was framed by the Hungarian language (Borsfay 2014: 80). Although it probably played a part in the difficulties of reaching potential Chinese interviewees, their major cause was to be found in other factors related to norms of communication conditioned by sociocultural and, to a lesser extent, possibly by gender factors.

The original research design of the complete project on ChineseHungarian intimate relations (including also the relations between Chinese families and Hungarian child carers) counted on the paid collaboration of an ethnic co-worker, a well-connected cultural consultant from the local Chinese community. Having searched for months, a second-generation Chinese university graduate, raised in Budapest and fluent in both languages, seemed interested, comprehensive of and willing to get involved in the research project. But she became paralysed when it came to actually contacting her local Chinese acquaintances or her parents for an interview or even for an informal conversation on intimate relations; so, in the end our cooperation could not work out. Alternately, a similar attempt was made with a Hungarian intermediary with connections in the Budapest Chinese community. After a series of failed efforts, he withdrew from the project. At this stage in fieldwork it seemed that, seen from the Chinese side, the whole idea of the research topic was transgressing implicit norms of communication. Later on, these experiences connected with the ethnic stereotypes of communication that a Hungarian and two Chinese female interlocutors referred to independently during our conversations. They shared the view that "the Chinese would never talk about the things most important to them. They would keep those thoughts only to themselves." There is no space here to discuss in the detail the implications of this statement for the study of intimacy, nevertheless it helped me understand and handle the challenge of rejections.

This notion also helped process the research experiences when two Chinese interlocutors denied or kept basic relationship information to themselves, presenting thus a modified version of their relationship stories. I'll present the case of an elderly Chinese lady whom I refer to as Madame Wu. She and her husband had met and married in China in the cold war era and decided to move to Hungary. After a series of communications, phone calls and e-mails we finally arranged an interview date with Madame Wu who had 
lost her Hungarian husband years before. A fluent speaker of Hungarian, she recalled vividly her first encounter and happy married life with her Hungarian husband and his parents, declaring it her life project to arrange and publish her late husband's academic legacy, presenting an overall picture of a long, happy, affectionate and successful marriage with shared interests and two children. Talking to a Hungarian friend about how fieldwork was advancing it was by accident that I learned that Madame Wu had divorced her Hungarian husband years before his death, an event that finally occurred in an old people's home. During the interview, I did not specifically ask if they had a divorce, since no hints were given that it could have been the case. Madame Wu did not see it necessary to provide me with this detail.

The relationship accounts manifest in the interviews showed very different degrees of articulation of and personal reflection on the specific issues influencing the everyday reality of mixed bonds (and families), ranging from simple, ethno-centric comments to highly elaborate and complex interpretations, primarily depending on partners' ethnic belonging and level of education. Fieldwork and the interview process indicated that the Chinese migrants present in Hungary were less willing to talk about their relationships than their Hungarian partners, and even when they decided to contribute they shared less about their emotions and everyday personal interactions within the relationship in the interviews. The likelihood that a person involved in a Chinese Hungarian relationship was accessible for this research seemed to have been influenced by a number of conditions such as gender, ethnicity, level of education, and economic success. In general, Hungarians were more likely to talk to me than Chinese, and women more likely than men; a Hungarian woman much more likely than a Chinese man; Chinese persons with a higher degree of education more likely than the ones without; economically very successful Chinese business persons less likely than Chinese employees or freelancers.

\section{Culturally embedded concepts}

The problematic of culturally embedded concepts in quantitative as well as qualitative migration research was addressed by Borsfay et. al. (2014) referring to the context of Hungary. Discussing the languages and specific terms used in questionnaires of migration research they drew the attention to the significance of the different cultural frameworks of interpretation of notions such as 'rootlessness', 'home', 'foreign country', or 'income'. These terms invited very different associations from their ethnically mixed group of migrant interviewees. During the research on Chinese Hungarian mixed 
couples the socio-culturally conditioned circles of associations of two central concepts, "marriage" and "family" marked a key dividing line in mixed couples' lives.

At the beginning of field research in $2013 \mathrm{I}$ had a lengthy conversation with Dr. Li, an elderly Chinese man living in Hungary, recommended to me as a well-integrated member of the Chinese community. Dr. Li was considered an intermediary between Chinese migrants and Hungarian locals by my first Chinese contact in the field, Mr. Yu. Dr. Li dedicated his entire professional life to learning and teaching Hungarian as a foreign language and became university professor of Hungarian at a prestigious university in China. He had spent several long periods in Hungary before finally getting settled in Budapest. I hoped that he would know mixed couples and help me contact them. He talked in Hungarian enthusiastically and I did my best to tell him that I intended to realize and anthropological study to understand the role cultural heritages played in the lives of Chinese-Hungarian mixed marriages. He seemed to follow what I said, he told me that once he had a failed relationship with a Hungarian woman, and that he couldn't help me by providing contacts because he did not have any. I was on my way home from the interview when he telephoned and told that there he was with his wife sitting next to him and that he thought that they could actually help me. He gave personal data of his wife's nephews, two Chinese men in their thirties who had arrived in Hungary a couple of months before. He named the prestigious Chinese restaurants where they worked as cooks, told me how much they earned per month and added that they were about the get a rise. They would be interested in marrying Hungarian women of their own age or maybe a little older but definitely not divorcees. I told him again that my interest in mixed marriages is not setting them up but studying the ones that already existed. I found this episode informative on how, in spite of communicating fairly fluently in the same language, the cultural embeddedness of certain concepts, such as 'marriage' and 'an anthropological study on mixed marriage' in a Chinese-Hungarian context may invite different culturally conditioned associations and drive a conversation onto separate tracks.

Another example highlights the culturally conditioned definition of 'family' of a typical Chinese businessman as perceived by Susan, his Hungarian wife in her mid-fifties, mother of his five children. Susan's husband's ideas of 'family' and 'family duties' determined basic structural aspects of their family life. Their case is analysed in more detail elsewhere (Kovács 2016), but in summary, Susan's definition of 'family' referred to her husband and their five children, while her husband's definition of family referred primarily to his 
parents, siblings, and more distant blood relatives, and his Hungarian wife and children came second leading to never ending and unresolvable conflicts in their lives, and finally to the separation of the couple.

\section{Masking identities}

Although it was possible to divide into different relationship categories, Chinese Hungarian mixed partner relationships do not involve a numerous population. Qualitative information, relationship histories, and life narratives could easily reveal individuals' identities. When asked to contribute to this research interlocutors were promised anonymity. Writing up research results started with hiding their real identities and replacing their names with pseudonyms. Episodes of their lives were used separately, without one making references to the others. There still remained some particularly revealing personal features (e.g. number children; gender of children; location of residence; profession; specification of business; etc.) that had to be hidden or altered decided on an individual basis after careful measuring. When details were changed in order to mask interlocutors' personal identities it was intended to be done in a way that the new sociocultural pattern associated with a person appearing in the final results would not be substantially different from the original. However, combining information available in online space with data gathered through face-to-face interaction signalled the limits of masking people's identities and raised dilemmas of whether or not and to what extent to use sources gathered through the internet.

\section{Personal position}

Notions such as marriage, family, childcare, or a 'good childhood' are heavily loaded with norms and values directly connected to one's own sociocultural background including the anthropologist; yet they tend to be implicitly thought of as universally human. An academically inspired interest in everyday human interpersonal interaction of a Hungarian female anthropologist combined with her personal ideas have inevitably influenced the formulation of (some of) the research questions. The question of how, let's say, a Chinese male researcher would go about the study of the same phenomenon kept intriguing me all through the fieldwork. (I think of this possibility as a methodological must for similar future research projects.)

The culturally conditioned norms and communication strategies mentioned previously combined with my gender, age, Hungarian ethnic background and language skills eased my way to women, especially Hungarian women, and limited especially my access to Chinese men's ideas about their 
relationships. This personal position seemed to have influenced the situations and the overall atmosphere of my encounters with (potential) interlocutors and also the quantity as well as the qualitative depths of the information in interviews. Conducting fieldwork in a fragmented field on numerous locations can also be accounted for the distance that remained between the anthropologist and the field in the majority of the situations. Fieldwork data and literature (Borsfay et.al. 2014) suggest that the presentation of a socially acceptable image of oneself including one's social relations is object of personal efforts in the Chinese context. In a way, the research fell victim to the social imperative of either hiding personal information or drawing a socioculturally conditioned ideal picture of ones' family relations, just as we saw it in the case of Madame Wu. Doing research in a fragmented field also decreased the anthropologist's visibility for the people she studied; however, interchanging e-mail messages and sending interview texts for revision helped balancing this.

\section{$X$. The 'public afterlife of ethnography' and the consequences of research}

This reference to Didier Fassin's term (2015) in the subtitle draws attention to the increasing need of and expectation from anthropologists to face and handle the social and political consequences of their research and its results, especially the ones that affect the people they study. How will an ethnography change the lives of the anthropologist' interlocutors? With respect to the present study this question arises more powerfully in a time when social and political tensions related to migrants and international migration dominate politics as well as public discourse all over the world.

When presenting results, the minimal personal principle was trying not to do any potential harm or risk to the people who contributed. As long as the products of research, conference presentations, papers, articles, book chapters stay within the restricted and isolated field of academia, chances of public repercussion of results and potential negative consequences (for researcher and interlocutors alike) are indeed low. Thinking of building blocks of a more positive vision of how the research on mixed couples may enhance interlocutors' lives, three potential themes are specified. Reading more than the abstract of an ethnographic article may contribute to a more profound understanding of migration related phenomena by breaking up ethnic stereotypes of migrants into ethnographic details that provide context and reveal motives of behaviour. Second, some of the interview situations, especially the ones that narrated failed marriages, seemed to have contributed 
to the interlocutor's process of elaboration of these life experiences. Their articulation and the interpretation of conflicting experiences contributed to their empowerment. Finally, research results, and especially the typical culturally conditioned causes of conflict could be used in marriage counselling and translated into useful pieces of advice; they could be turned into a bilingual Guide to Chinese-Hungarian Interethnic Partner Relationships, for actual and potential members of such bonds.

\section{Conclusions}

This paper aimed to reflect on the process of the construction of the ethnographic field as defined by its object of study, Chinese Hungarian mixed partner relationships. The research was driven by the assumption that first generation Chinese entrepreneurs and Hungarians only rarely engaged in a romantic relationship. I had to face several methodological challenges during the interpretive anthropological attempt to understand the everyday reality and the sociocultural factors influencing the dynamics of intimate bonds between Chinese and Hungarian persons. The anthropological fieldwork presented here meant to answer two sets of research questions; one set targeted partner relationships, while the other focused on the relations between Chinese families and their Hungarian child carers. The particular methodological problems related to the latter were not included in this work.

Some methodological difficulties were typical of extensive and extended anthropological fieldwork, such as handling information coming from third parties and socioculturally conditioned strategies of communication, working with culturally embedded concepts, or assuming the consequences of the researcher's personal position in the field. The problem of masking interlocutors' identities takes us to that group of methodological challenges that was conditioned by computer mediated communication and audio-visual sources from the world of the internet. The borders of my ethnographic field were outlined step by step following the research topic, the specific research questions, and experiences gained through fieldwork. During the research on Chines Hungarian marriages almost all methodological problems had to be faced that were discussed in a volume on migrant research methodology in Hungary ( Kováts \& Várhalmi 2014), the most important of them being missing information. Let me close this with Durham's ideas on the epistemological complexity of what she considers 'good anthropology'. She argues that 'good anthropology' also implies the 'ability to be comfortable with partial conclusions' and 'epistemological uncertainty' (Durham 2016: 7). 


\section{Acknowlegments}

The project received financial support from the Hungarian Scientific Research Fund (OTKA).

\section{References}

Beck, F. (2015). "De ha a tükörbe nézek, az arcom kínai. Másodgenerációs kínai fiatalok hibrid identitáskonstrukciói". MAKAT Antroport. Budapest $59 \mathrm{p}$.

Borsfay, K., Mikes, H., Török, L. (2014). "Bábeli útvesztő - Nyelvi kérdések s kvantitatív és kvalitatív kutatás során”. In Kováts, A., Várhalmi, Z. (eds). A válasz̧biányok kezelésétöl a résżtvevő megfigyelésig. Módszertani problémák a migrációkutatásban. ICCR: Budapest.

Clifford, J. (1997). "Spatial Practices: Fieldwork, Travel, and the Disciplining of Anthropology". In Gupta, A., Ferguson, J. (eds.) Anthropological Locations: boundaries and grounds of the field science. Berkeley, Los Angeles, Londres: University of California Press, pp. 185-222.

Durham, E. (2016). The "Good-Enough Anthropologist" Available at: http://somatosphere.net/2016/08/the-good-enough-anthropologist.html Accessed: 2017.04.06. 13:47.

Efron Pimentel, E. (2000). "Just How Do I Love Thee?: Marital Relations in Urban China". Journal of Marriage and Family 62 (1): 32-47.

Fassin, D. (2015). "The Public Afterlife of Ethnography". American Ethnologist 42 (4): 592-609.

Hine, C. (2000). Virtual ethnography. London, Thousand Oaks, New Delhi: Sage Publications.

Kovács, É., Melegh, A. (eds). (2010). ““Azt hittem célt tévesztettem”. A bevándorló nők élettörténeti perspektívái, integrációja és a bevándorlókkal kapcsolatos attitűdök nyolc európai országban”. KSH Népességtudományi Kutatóintézet: Budapest.

Kovács, N. (2015). "Cultures Unfolding: Experiences of Chinese-Hungarian Mixed Couples in Hungary". Current Issues in Personality Psychology 3 (4): 254-264.

Kovács, N. (2016). "Global Migration and Intermarriage in Chinese-Hungarian Context”. In Ducu, V., Telegdi-Csetri, Á. (eds). (2016). Managing Difference in Eastern-European Transnational Families. Frankfurt: Peter Lang, pp. 113-131.

Kováts, A., Várhalmi, Z. (eds). (2014). A válasz̧biányok kezzelésétól a résztvevó megfigyelésig. Módszertani problémák a migrációkutatásban. Budapest: ICCR.

Malinowski, B. (1922). Argonauts of the Western Pacific. London: Routledge.

Marcus, G. E. (1995). "Ethnography in/on the World System. The Emergence of Multi-Sited Ethnography”. Annual Review of Anthropology (24): 95-117. 
58 Romanian Journal of Population Studies • Vol. XI, No. 1

Nagy, K. Z. (2015). “Ösvény a dzsungelben”. Replika 90-91: 39-56.

Nyíri, P. (2010a). "Egy transznacionális "közvetítő kisebbség”: kínai vállalkozók Magyarországon”. In Feischmidt, M. (ed.). Etnicitás. Különbségteremtō társadalom. Budapest: Gondolat-MTA Kisebbségkutató Intézet, pp. 141151.

Nyíri, P. (2010b). "Kínai migránsok Magyarországon: Mai tudásunk és aktuális kérdések" [Chinese migrants in Hungary. What we know today and relevant issues]. In Hárs, A., Tóth. J. (eds). (2010). Változó migráció változó környezet [Changing migration in a changing context], Budapest: MTA ENKI, pp. 147-171.

Nyíri, P. (2006). "Kínaiak és afgánok Magyarországon: két migráns csoport érvényesülési stratégiái”. In Feischmidt, M., Nyíri P. (eds). Nem kivánt gyerekek? Külföldi Gyerekek magyar iskolákban. Budapest: MTA NemzetiEtnikai Kisebbségkutató Intézet - Nemzetközi Migrációs és Menekültügyi Kutatóközpont, pp. 39-74.

Örkény, A., Székelyi, M. (eds). (2010). Az idegen Magyarország. Bevándorlók társadalmi integrációja. Budapest: Kisebbségkutató Intézet.

Sonnenberg, B. (2014). Mechanisms of unemployment and social involvement. Findings from the Socio-Economic Panel Study (SOEP) Springer: Wiesbaden.

Szabó, M. (2009). "Why Would We Need a Chinatown?” The Case of Chinese Entrepreneurs in the Rust Belts of the 8th and 10th Districts of Budapest. [Master's Thesis]. Budapest: Central European University, Department of Sociology and Social Anthropology.

Szilassy, E. (2006). ““'Én nem vagyok rasszista, csak utálom a kínaiakat meg a négereket" - a külföldiekhez való viszony a magyar serdülők beszédében”. In Feischmidt, M., Nyíri P. (eds). Nem kivánt gyerekek? Külföldi Gyerekek magyar iskolákban. Budapest: MTA Nemzeti-Etnikai Kisebbségkutató Intézet- Nemzetközi Migrációs és Menekültügyi Kutatóközpont, pp. 97-127.

Várhalmi, Z. (2009). "A Távol-Keletről Magyarországra érkezô állampolgárok munkavégzésének fő jellegzetsségei, típusa. (Kutatási zárótanulmány)”. MKIK Gazadsági és Vállakozáselemzó Intézet.

Várhalmi, Z. (2013). "Vállalkozó migránsok Magyarországon". In Kováts, A. (ed.). Bevándorlás és integráció. Magyarországi adatok, európai indikátorok. MTA Társadalomtudományi Kutatóközpont, pp. 89-100. 